\title{
A PRELIMINARY STUDY OF ACADEMICIANS' PERCEPTION TOWARDS WOMEN ON BOARDS IN MALAYSIAN PUBLIC LISTED COMPANIES
}

\author{
Farhana Hasbolah \\ farhana.hasbolah@unisel.edu.my \\ Department of Accounting and Finance, Universiti Selangor (UNISEL) \\ Mohamad Hafiz Rosli \\ kaptenhafizrosli@gmail.com, \\ Faculty Of Accountancy, Universiti Teknologi MARA, Cawangan Johor, Kampus Segamat, \\ Johor, Malaysia \\ Siti Aisyah Omar \\ aisyahomar@unisel.edu.my, \\ Department of Accounting and Finance, Universiti Selangor (UNISEL)
}

\begin{abstract}
Gender diversity in the corporate board is still an issue for certain countries including Malaysia. The Malaysian Code of Corporate Governance (MCCG) 2017 anticipates 30\% of women to be on the corporate board. However, recently the number of women on board reported is still lower. This study aims to examine the perception of academician towards women on board (WOB). The survey questionnaires were sent among academicians. The result indicates that the academicians believe that the appointment of women on boards will improve and enhance the companies' performance. There are equal opportunities for men and women to be in management positions. The finding of this study will assist the policymakers and companies especially in formulating women policy to support the national agenda.
\end{abstract}

Keywords: Board of Directors, Corporate Governance, Malaysian Code of Corporate Governance 2017, Public Listed Companies, Women Directorship,

\section{INTRODUCTION}

Gender diversity in the corporate board is one of the important parts to enhance board performance. The involvement of women directors in the corporate board has been seen as still minimal especially in Malaysia. Despite the encouragement given by the government, the perceptions of accepting women as corporate directors are still debatable. The policy on gender diversity in Malaysian Public Listed Companies (PLC) is mentioned in the Malaysian Code of Corporate Governance (MCCG) 2017. MCCG 2017 practices indicate that "the board discloses in its annual report the company's policies on gender diversity, its targets, and measures to meet those targets. Furthermore, for Large Companies, the board must have at least 30\% of women directors" (Securities Commission of Malaysia, 2017). It has been a significant tool for corporate governance reform and has influenced the corporate governance practices of companies positively.

Reports from the Institute of Corporate Directors Malaysia (ICDM) indicate that women representation on boards of all PLCs on Bursa Malaysia accounted for 16.6\% and 15.6\% were as of September 2019 and 2018 respectively (Saieed, 2019). This indicates that the 
number of women directors is still lower among Malaysian PLC. Meanwhile, within the top 100 publicly listed companies, women's participation as board members has increased to $24.4 \%$ in 2018 as compared to $19.27 \%$ in 2017 . The target of having $30 \%$ women on the board of directors of 100 leading Malaysian PLC by 2020 is achievable given the current participation level at 24\%. The Corporate Governance Monitor Report 2019 reported that the appointment of women directors was made between the age of 20 to 40 years old and mostly hold executive positions on the board of directors in companies listed in the industrial products and services sector and also the consumer and services products sector. If the percentage of women continues to increase among the younger age group, it can therefore support the continued participation of women on the board.

Despite this minimal number, previous research indicates that the involvement of women directors would enhance the performance and reputation of the business (Ali et al. 2014; Chapple and Humphrey 2014; Brammer et al. 2009; Bernardi et al. 2006). However, Abdullah, Amran, and Ishak (2017) argued that women on board have no impact on value creation. They were still considered unprepared and qualified to take on responsibilities as board members even though they are identified as capable of occupying the board seats. The results of studies conducted in Malaysia and globally clearly show that women are still marginalized in these aspects given the system, structure, practices, and thinking of society that is inclined towards patriarchal thinking that is detrimental to the country. Having women on the board of directors could help management better understand the perspectives of clients and the workforce, and gain deeper knowledge and involvement for its stakeholders. Therefore, it leaves a question of why women directors are not employed as a board member?

There were limited studies that were conducted with the perceptions of academicians towards the women directors in Malaysian PLC. Therefore, this study aims to examine the perception of women on boards among academicians. The paper contributes to the existing literature by adding a new perspective of the academicians towards women on boards into the literature. In practical terms, this study contributes to giving possible recommendations to the practitioners in formulating relevant policies to support the national agenda. This paper is structured; first, we review the literature on board gender diversity drivers, followed by the research methodology, findings, and discussion. The last part discusses the conclusion of our research.

\section{LITERATURE REVIEW}

Good corporate governance helps companies to improve performance, as well as achieving long term value creation for the shareholders. It outlines the laws and norms that shape relationships between the board of directors, shareholders, and managers. Generally, the definition of good corporate governance is to determine the distribution of rights, responsibilities between the board of directors, managers, employees, shareholders, and lawmakers to make decisions on the business affairs of organizations (La Porta et al., 2000). Companies with many women representatives on the board of directors and management positions have proven to perform better than companies with fewer or no women directors. Studies have shown that gender equality contributes to the company's financial performance (Bennouri, Chtioui, Nagati \& Nekjili, 2018; Verma, 2013; Choudhury, 2015; Nguyen, 2017; Bart \& McQueen, 2013). Many of the executives are convinced that having more women as directors will improve companies' performance.

Besides, the higher number of women on boards did not affect earnings management and 
good corporate governance practice (Faten, Amal, Nadia \& Adnane, 2015). Amongst the characteristics that should be adhered to to implement good governance are transparency, accountability, responsibility, and honesty. These characteristics need to be nurtured in all administrative aspects and exhibited in all board members' actions and decisions irrespective of gender (Zelhuda, Abdul Ghafar, \& Bayu, 2014). A study conducted by Soong and Hooy (2016) has discussed the difference between having the right number of women on boards and having more women on boards where the first one enhances the company's performance in comparison to the latter. Women are capable of leading the company effectively and efficiently as well as carrying the role of a leader magnificently (Trinidad \& Normore, 2005). They have the competency in monitoring and advising the management whilst participating in the boardroom more actively. There are over enough qualified, competent, and skilled women directors available to sit in the top management position (Mahalakshmi \& Narayana, 2017).

However, there are barriers to opportunities within the company that prevents women from advancing and entering management positions (Emulti, Jia \& Davis, 2009); namely discrimination, family life demands, prejudice, and stereotyping. Amongst these, family responsibility could be a leading factor that obstructs women to achieve leadership positions (Sam, Amartei, Owusu \& Owusu, 2013). It is an enormous challenge for women to balance their career and family commitments. They need help and support from husbands and family to be able to contribute better and be productive in the workplace. On top of that, there are still many that do not believe in the ability and flexibility of women leaders in the workplace. Gender parity continues to be far off and women often are seen as weak and do not have any leadership values and are often evaluated and compared to men's leadership styles. Hence, it is encouraged for women to be given the opportunity as decision-makers to further increase the involvement of women in the corporate sectors.

For the boardroom to be effective, it requires diversified talents and skills to form impactful decisions for companies. In keeping with Hilal (2015), the efficiency attribute was rated as the most common attribute associated with women's leadership followed by collaboration and affection. By having women on board, the board can make fair decisions by taking into consideration the interest of most stakeholders. This is often because of the character of women who seems to be more meticulous by having higher reasoning skill compared to men (Bart \& McQueen, 2013). Similarly, Tu (2017) in his study has found a positive influence and effect on corporate governance by having women on board. Furthermore, the findings were also supported by Terjesen, et. al (2009) as their study found that corporate governance is often improved by having a full talent pool's capital by building more inclusive and fairer business institutions that better reflect their present generation of stakeholders.

For some countries, women's participation on board is greatly welcomed, and that they enjoy a respectable position equivalent to male directors, either in public or private companies (Hossain \& Noor, 2016). However, in another country, it is difficult to open the door for women to be on board. It had been revealed that the presence of women on board does not influence the company's performance (Shabbir, 2018). In addition to that, being stereotyping and using gender as a reason to discriminate against women from entering board due to certain unmet criteria and lack of leadership traits have restricted the participation of women to be on board (Pajo, et. al, 1997; Baker, 2014). Thus, an effort to eliminate the old stereotypes about women's capability or traits and stressing on the advantages of having women on board has to be put by the authority to allow women to possess equal rights and chances to be on board. 
Powell and Graves (2003) mentioned that feminine stereotypes could influence the effectiveness of management and leadership in determining whether the leader could be a good leader or not. Through the stereotypes, the employees were able to assess what are the characteristics needed in selecting leaders especially at work (Harriman, 1996). A study by Adams and Ferreira (2009) revealed that women on board have better attendance records than males on board, and women are more likely to join monitoring committees. Women leaders have to be charismatic and highly motivated. They will inspire and motivate employees to attain a high level of work performance, and at the same time be prepared to avoid conflicts at work. Having said that, the government of Malaysia is committed to improving women's achievement, including ensuring equal opportunities in the various fields between men and women (Malaysian Budget, 2020). The conflicts are going to be even greater with the employment of technology and automation brought by the Industrial Revolution 4.0.

\section{RESEARCH METHODOLOGY}

This study employs survey questionnaires as a quantitative approach to data collection, was designed and tailored to academic settings. The survey form consists of section A (demographic information) and section B (academic perceptions towards women on board). Data for section B is gathered using a five point Likert scale that range from 1 (strongly disagree) to 5 (strongly agree), consists of four components namely Companies"Performance, Opportunities, Credibility, and Leadership. An invitation letter and the survey form were distributed among 50 academicians particularly in the business and management field in three universities in Shah Alam Selangor. The selection of those academicians in the business and management field because they are more understanding of corporate governance and business aspects. However, there are only 32 of the questionnaires were received. After the screening process, there are 2 incomplete questionnaires. Therefore 30 questionnaires were taken into this study with $63.3 \%$ of the response rate.

\section{RESULT AND DISCUSSION}

\subsection{Demographic profile}

The respondents consist of $67 \%$ (20) women, $80 \%$ (24) master degree qualification, and $80 \%$ (24) have 6 - 10 years of working experience. Meanwhile, 80\% (24) of the respondents have acquired 0-5 years of industrial experience before attached to academic institutions. It is also interesting to note that, $50 \%$ (15) of the respondents have acquired professional membership. Table 4.1 indicates the mean analysis of five tested variables consists of Companies Performance, Opportunities, Credibility, and Leadership.

\subsection{Analysis of women directorship}

Table 4.1: Mean analysis

\begin{tabular}{lc}
\hline Variables & Mean \\
\hline Companies' Performance & 4.22 \\
Credibility & 4.05 \\
Leadership & 3.77
\end{tabular}


Table 4.1 indicates all the mean of tested variables. Four tested variables name companies' performance; opportunities, credibility, and leadership were used. Company performance, credibility, and leadership are to reflect the women directors' capability to be on board. Meanwhile, opportunities are looking to the potential chance given to the women to become directors. The highest means score reported is Companies performance (4.22). This study indicates that the involvement of women on board enhances company performance. The respondent also agrees that women on boards will improve the levels of psychological well.being with the reported mean score of 4.40. Most of the respondents also agree (mean score $=4.40$ ) that there should not be any restriction factors for women to be on boards such as gender, race, religion, ethics, physical, and others. On top of that, there should be more women on boards with relevant qualifications and business experience (mean score $=4.60$ ) also consistent with the previous study conducted by Ismail, Abd. Rahman, Mustapa, and Abdullah (2017) stated that education, expertise, and leadership qualities are necessary for women to reach the boardrooms.

It is also interesting to remark that, women on boards can exercise their power (mean score $=$ 4.00). From table 4.1, the least score reported is Opportunities (means score $=3.70$ ). It indicates that less opportunity is being provided for women to be board candidates. The respondents agree that the requirement of $30 \%$ women on board is relevant and should be increased (mean score $=4.20$ ). Another reason for the less opportunity to be on board is that women need to have professional qualifications (mean score $=4.60$ ). Although society is now seen to be ready to accept women as leaders they need to work even harder and show results that are twice pretty much as good as men leaders. As a result of the diligence of women who want to prove their abilities in leadership, it can increase the society's confidence and indirectly reduce the stereotypical or prejudicial and pessimistic of society. Gender discrimination or denying the right of women to be given the same access and consideration as men are detrimental to the country. Women today have the ability not only in terms of academic achievement but also in many women who have the abilities and skills to fill the highest positions in the organizations.

\subsection{Academic Perception Behavior}

Table 4.2: Academic Perception Behavior

\begin{tabular}{lc}
\hline Variables & Mean \\
\hline Women leaders are fussier than men leaders & 4.40 \\
Women leaders are inflexible than men leaders & 4.00 \\
Women leaders tend to be biased than men leaders to a certain extent & 4.00 \\
Women leaders tend to make a decision based on emotion & 4.00 \\
I can work well with women leaders & 3.80 \\
I can communicate well with women leaders & 3.80 \\
I prefer that my immediate superior is a woman & 3.60 \\
I trust women leaders more than men leaders & 3.60 \\
My career advancement can be attributed to my experience working with & 3.60 \\
women leaders & \\
I achieved good performance evaluation because it was assessed by women & 3.00 \\
\hline
\end{tabular}


Despite all positive feedback, academician perception is also interesting to be remarked. Table 4.2 shows that all respondents agree (mean score $=4.00$ ) that women leaders are inflexible than men leaders, tend to be biased than men leaders to a certain extent and tend to make a decision based on emotion. Besides, the respondent rated women leaders are fussier than men leaders (means score $=4.40$ ). Most of the respondents were less likely to agree (means score $=3.00$ ) that they will get good performance evaluation if it is assessed by women leaders. Nevertheless, the majority of them agreed that they can work well and communicate with women leaders (Means score $=3.80$ ). Some of the respondents are in agreement (means score $=3.60$ ) that they prefer women leaders because they trust women leaders as compared to men leaders.

Previous researchers (Powell \& Graves, 2003; Harriman, 1996) mentioned that the connection between leadership style and gender differences has led to the emergence of gender issues or feminine stereotypes in leadership in the organization, particularly women leadership. The phrase "she is a natural leader" describes a person as having the characteristics that qualify her to be a leader (Northouse, 2007). It emphasizes the interaction between leaders and followers through developing talent and skills at work. The finding from the study is consistent with previous research where the respondents (means score $=3.60$ ) believe that their career advancement can be attributed to the experience of working with women leaders.

High quality of leadership is needed to manage and administer department, faculty, and university as a whole to produce good students. The women leaders who have held the position of head of departments, deputy deans, and deans should be forward-thinking, proactive, have high creativity, and bold in making changes in the interest of the future students to be in line with the changes in the environment (Collard, 2001). As the global economy and industry evolve, the educators are encouraged to equip themselves with the knowledge of the Internet of Things (IoT) to meet and respond to the challenges of the Industrial Revolution 4.0 enthusiastically. As a consequence, women leaders at the faculty should choose the best leadership style to be able to motivate academic and non-academic staff to be more interested and committed to the policies set by the university. Kochan, Spenser, and Mathew (2000) argued that it was not easy for the women leaders to instruct staff under their leadership to be responsible and accountable in carrying out their duties.

In less than a month, Malaysia will be entering the year 2020, which a year that everybody is waiting for a long time. In the context of a developing country towards a developed nation by 2020, Malaysia needs a leader which has an excellent academic background and can adapt to the changing environment to meet current challenges and ready for the future.

\section{CONCLUSION}

In conclusion, analysis from this study indicates that women onboard resulted in enhancing the company performance however, this study also indicates the perception of academicians towards women to be on board. The companies ${ }^{\text {ee }}$ performance was perceived as a leading factor for women to be on boards and attain management positions. More women on board will enhance the quality of the boardroom and improve the company'se performance. The findings also indicate that the academicians believe that women and men have equal opportunities to advance in higher positions. The appointment of women to be on board should be based on professional and academic qualifications rather than on gender and stereotypes. 
Although this study drew a broader picture of the academicians' perception towards women on boards in Malaysian PLC, due to the small number of participants, it is not possible to generalize the results because of different environments and situations. Based on the findings, there is a need for further investigations to be carried out in the future in order to extend these findings in different context. Therefore, some suggestions for future studies were proposed. The larger and more diverse sample size is important so that data will be more applicable to the increasingly diverse academicians' population in Malaysia. The statistical data can be collected employing a qualitative approach, for example semi structured interviews to provide a deeper understanding of the subject. The relationship between the perception of the academicians and behavior could even be further investigated. Nevertheless, this study provides significant insight into various parties such as the policymakers, public listed companies, potential women board members, and other researchers. As this study highlights the significance of women to be on board, it will assist the policymakers and companies especially in formulating women policy to support the national agenda.

\section{REFERENCES}

Adams, R., and Ferreira, D. (2009). Women in the boardroom and their impact on governance and performance. Journal of Financial Economics, 94 (2), 291 - 309

Ali, M., Ng, Y. L., \& Kulik, C. T. (2014). Board age and gender diversity: A test of competing for linear and curvilinear predictions. Journal of Business Ethics, 125 (3), 497-512.

Baker, C. (2014). Stereotyping and women's roles in leadership positions. Industrial and Commercial Training, 46 (6),332-337.

Bart, C., and McQueen, G. (2013). Why Women Make Better Directors. International Journal of Business Governance and Ethics. 8 (1)

Bennouri, M., Chtioui, T., Nagati, H., and Nekhili, M. (2018). Female Board Directorship and Firm Performance: What Really Matters? Journal of Banking and Finance, 88, 267-291

Bernardi, R. A., Bosco, S. M., \&Vassill, K. M. (2006). Does female representation on boards of directors associate with Fortune's 100 best companies to work for the list? Business and Society, 45(2), 235-248.

Brammer, S., Millington, A., \& Pavelin, S. (2009). Corporate reputation and women on the board. British Journal of Management, 20 (1), 17- 29.

Chapple, L., \& Humphrey, J. E. (2014). Does board gender diversity have a financial impact? Evidence using stock portfolio performance. Journal of Business Ethics, 122(4), 709-723.

Choudhury, B. (2014). New Rationales for Women on Boards. Oxford Journal of Legal Studies, 34 (3), 511-542

Emulti, D., Jia, H., and Davis, H. H. (2009). Challenges Women Face in Leadership Positions and Organizational Effectiveness: An Investigation. Journal of Leadership Education, 8(2)

Faten, L., Amal, A., Nadia, L., and Adnane, M. (2015). Do Women on Boards and in Top Management Reduce Earnings Management? Evidence in France. Journal of Applied Business Research, 31 (3) 
Harriman A (1996). Women / Men /Management. Greenwood Publishing Group Hilal. H. (2015). Perceptions of Female Leadership in Malaysia. Journal of Modern Education Review, 5 (5), 517-525.

Hossain, T., and Noor, M. A. (2016). Perception Towards Women Leadership In Bangladesh: A Comparative Study Between Public And Private Sector. International Journal of Economics, Commerce, and Management. 4 (11), 319-328.

Ismail, K.N.I.K., Abd. Rahman, I.M., Mustapa, I.R., and Abdullah S.N. (2017). What it Takes for Women to Reach the Corporate Boardrooms in Malaysia. Corporate Ownership \& Control, 14 (3-2)

Malaysian Budget of 2020. KementerianKewangan, Malaysia

Mahalakshmi, V., and Narayana, P. R. (2017). Corporate Governance and the Presence of Women Director on Boards. Journal of Business and Management, 19 (1), 59-64

Nguyen, T. C. T. (2017). The Impact of Female Board of Directors on Firm Performance and Dividend Payout Policies: Evidence from Vietnam. International Research Journal of Finance and Economics, 164

Northouse, P. G. 2007. Leadership: Theory and practice. California: Sage

Pajo, K., McGregor, J., and Cleland, J. (1997). Profiling the pioneers: women directors on New Zealand corporate boards. Women in Management Review, 12(5), 174-181.

Powell GN, Graves LM (2003) Women \& men in management. 3rd ed. Sage Publication, Inc., United States of America.

Saieed, Z. (2019, October 17). Women's representation on PLC boards is still low. Retrieved November 13, 2019, from https://www.thestar.com.my/business/businessnews/2019/10/17/women-representation-on-plc-boards-is-still-low.

Sam, F. K., Amartei, A. M., Owusu, B. O., and Owusu, A. (2013). Female Leadership Stereotypes: The Perception of the Leadership of Female Heads of Senior High Schools in Ashanti Regions. International Research Journals, 4 (10), 702-709

Securities Commission of Malaysia (2017). Malaysian Code of Corporate Governance (MCCG) 2017, Kuala Lumpur, Securities Commission Malaysia

Shabbir, M. S. (2018). Women on Corporate Boards and Firm Performance, Preliminary Results from Italian Listed Companies after the Introduction of Gender Quota Law. Journal of Business Finance, 7(1), 316

Soong, Y. Q. and Hooy, C. W. (2016). Does Women Directorship in Malaysian Government Linked Company Matters? Journal of Contemporary Issues and Thought, 6, 83-92

Tersejen, S., Sealy, R., and Singh, V. (2009). Women Directors on Corporate Boards: A Review and Research Agenda Siri: Corporate Governance. An International Review, 17 (3), 320-337

Verma, S. (2013). A Move towards gender-balanced Boards: Exploring Women Participation on the Boards. Global Journal of Management and Business Studies, $10,1101-110$ 